総説

\title{
蟒結・粒成長シミュレーションの研究と技術開発
}

\author{
松原 秀彰 \\ 勛ファインセラミックスセンター，テ456-8587 名古屋市熱田区六野 2-4-1.
}

\section{Studies and Technical Development of Computer Simulation for Sintering and Grain Growth}

\author{
Hideaki Matsubara \\ Japan Fine Ceramics Center, 2-4-1 Mutsuno, Atsuta-ku, Nagoya 456-8587.
}

Received July 9, 2004

\section{SYNOPSIS}

We have successfully developed a computer simulation technique to design microstructural development such as sintering and grain growth of nano/micro-size particles by using the Monte Carlo (MC). The MC simulations were performed for the array of two- or three-dimensional lattices. Plural mechanisms of mass transport were introduced in the $\mathrm{MC}$ simulations of sintering and grain growth in ceramic systems, which involve a liquid phase and second solid particles. The MC simulation was applied to the microstructural development of sintering and grain growth at the solid state and in the presence of a liquid phase. The compound effects of the second particle, liquid phase and anisotropy were successfully analyzed by the $\mathrm{MC}$ simulations in order to design complex and important microstructures in ceramics. The MC simulations are useful for microstructural design on a lot of materials of grains and particles. KEY WORDS

computer simulation, sintering, grain growth, material design, powder metallurgy

\section{1 はじめに}

粉末 (粒子) 状の物質を加熱すると固まる璝象は，焼結 (sintering) と呼ばれ，セラミックス，金属サーメット系の工業 材料の製造法として広く利用されてきている ${ }^{1)}$.焼結に関する 科学的な研究も, 実験的または理論的な両面から多くの研究 がこれまでに行われてきている．粉末が焼結するということ は, 現象論的な観点からは非常に分かりやすい過程であるが, 物質移動論的な観点からは必ずしも分かりやすい過程ではな い. 例え単一成分, 単相の焼結過程でも，体積拡散，表面・粒界 拡散など複数の物質移動機構が働く．ましてや現実の材料系 (多成分，多相など)の焼結では，極めて複雑な物質移動が生 じる、㮱結の理論研究が古くから行なわれているにもかかわ らず，焼結材料の設計手法として発展しにくい大きな理由の 一つは, 従来理論では単一の物質移動機構による解析がほと んどであり，現実との間に大きな溝(ギャップ)があるためで ある.

焼結のコンピューター・シミュレーション研究の大きな意 義の一つは，従来の理論研究では成しえなかった複合的でか つ複雑な(相互作用のある)過程を表現し，さらには現実的な
過程を予測または設計する技術を開発することにある．本稿 では，著者らが研究を進めている焼結・粒成長の組織形成シ ミュレーションについての主な研究成果 ${ }^{4-18)}$ を紹介し, 材料設 計技術への応用展開についてもふれる.

\section{2 㛙・粒成長研究の歴史とシミュレーションへの展開}

Table 1 には，焼結および粒成長の研究の歴史をまとめた. これまでの焼結の理論研究においては，おおむね単一の機構 モデルによる取り扱いが中心であった．例えば，固相粒子の 焼結の理論の場合には，粒子のネック成長の過程が表面拡散 機構などの単一機構によって行われるときのネック曲率の変 化などが数式化されている.しかし，実際の材料の組織は，例 え純粋なものであっても，単一の機構によって形成されてい るとは考えにくい.

固相の焼結の終期過程になると，ポアはいわゆる閉気孔と なって存在し，その消滅は粒界を通した搪散によって行われ るようになる。これと共に，粒界の移動も活発となり，これ に対してポアの存在が影響するという現象が生じる.つまり ポアと粒界が相互作用をしながら，焼結と粒成長の過程が進 
Table 1 History of theoretical studies on sintering and grain growth.

\begin{tabular}{|c|c|c|}
\hline \multicolumn{2}{|c|}{ Researchers (year) } & \multirow{2}{*}{ theories } \\
\hline sintering & grain growth & \\
\hline Kuczynski (1949) & & Diffusion Model \\
\hline \multirow[t]{3}{*}{ Herring (1950) } & & Scaling Law \\
\hline & Burk and Turnbull (1952) & Kinetics in Pure Materials : $R^{2}-R_{0}^{2}=K t$ \\
\hline & Zener (1953) & Pinning Effect by Dispersoids \\
\hline Kingery (1955) & & Kinetics and Experiments \\
\hline Coble (1961) & & Diffusion Model (Grain Boundary's Role) \\
\hline \multirow[t]{6}{*}{ Kingery (1961) } & & Lıquid Phase Sintering \\
\hline & Lifshitz and Slyozov (1961) & Kinetics for Ostwald Ripenning : \\
\hline & Wagner (1961) & $R^{3}-R_{0}^{3}=K_{d} t$ (Diffusion Control) \\
\hline & & $R^{2}-R_{o}^{2}=K_{r} t$ (Reaction Control) \\
\hline & Cahn (1962) & Impurity Drag Effect \\
\hline & Hillert (1965) & Abnormal Grain Growth \\
\hline Nichols (1968) & & Simulation of Sintering (Surface Diffusion) \\
\hline Brook (1969) & & Interaction of Pore and Grain Boundary \\
\hline Ashby (1974) & & Sintering/HIP Map \\
\hline German and Lathrop (1978) & & Computer Simulation of Neck Growth \\
\hline \multirow{3}{*}{ Harmer and Zhao (1983) } & Novikov (1978) & Computer Simulation by Statistical Model \\
\hline & & Map Method (Porosity vs. Grain Size) \\
\hline & Anderson, Srolovitz, et a!. (1984) & Monte Carlo Simulation (Potts Model) \\
\hline Lange (1984) & & Analysis for Inhomogeneity \\
\hline Rödel and Glaeser (1990) & & Pore Drag and Pore-Boundary Separation \\
\hline Chen, Srolovitz, et al. (1990) & & Simulation of Final-Stage Sintering \\
\hline
\end{tabular}

行するようになる。このような相互作用を最初に理論化した のがBrook ${ }^{2)}$ であり，複数の過程を同時にしかも解りやすい形 で示した理論研究の最初の例としての意義は大きい.

焼結や粒成長のシミュレーションに求められることは，大 量の原子移動の取り扱いが可能で, しかも複数の物質移動機 構が同時に扱えることである，そして，そのようなシミュ レーションでは，組織形成というプロセスが複数の物質移動 機構の相互作用の下で行われていることが示されなくてはな らない，筆者らは，セラミックスの焼結が，複合的な物質移 動機構から生じていると考え，固相の粒成長，液相を介した 固相の粒成長 (オストワルド成長) や液相の存在下で焼結 (液 相焼結)などの過程を，お互いの現象や設定条件が相互作用す る形でのシミュレーション開発を進めてきた.ここでは，確 率論的手法であるモンテカルロ (MC) 法をべースとした Potts Model $^{3)}$ と呼ばれる演算法, 計算格子を用い, 独自のプログラ ムによるソフトウエアー開発を行っている.

MC 法は確率論的な計算法で，エネルギ一の值あるいは相 対值がわかっていれば，とにかく動かしてエネルギー滅少の 確率関数で実行を決める方法である. 原子・分子の集合体を 単位セルとして動かすので，大量の物質移動を取り扱うこと が可能である．固相状態の単相多結晶体の粒成長，液相存在 下の粒成長，固相状態の焼結，液相存在下の暁結の 4 つのシ ミュレーション・プログラムは，すべてモンテカルロ法を計 算原理とする.

Fig.1に三角(六角)格子によるMCシミュレーションの原理
図を示す。ここでは，異なった種類(図では4種)の単位格子 を考え, 同種の格子の領域が結晶粒, 異種相あるいはポア(空 隙)を意味し，それらの境界が粒界, 界面あるいは表面を意味 する. 格子の変化試行によるエネルギ一変化 $\Delta \mathrm{G} に$ 基づく確率 関数 $\mathrm{W}$,

$$
\begin{array}{cc}
\mathrm{W}=\exp (-\Delta \mathrm{G} / \mathrm{kT}) & \Delta \mathrm{G}>0 \\
1 & \Delta \mathrm{G} \leqq 0
\end{array}
$$

の式によって求め, 0 から 1 までの間で乱数 $\mathrm{R}$ 発生させ, $\mathrm{W}$ ミRのとき試行を実行させる. 焼結や粒成長 (液相存在下も)含 めて)の過程はすべてエネルギー減少の過程であるので, MC シミュレーションの適用が可能である.

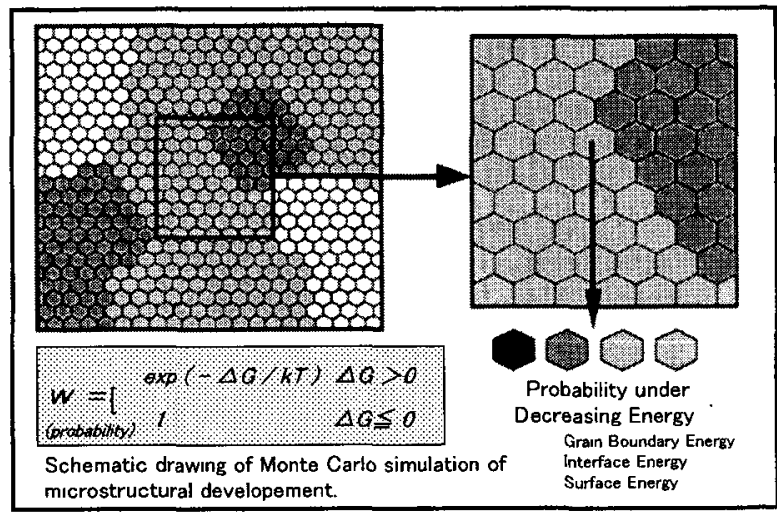

Fig.1 The triangular lattice and the probability function used for the $\mathrm{MC}$ simulation of grain growth and sintering. 
単相多結晶体の粒成長は，最も基本的なシミュレーション である．組織は $\mathrm{n}$ 種の方位からなる結晶とし，異種結晶方位 の格子の間(粒界に相当する)には，同種の格子の間よりも過 剩のエネルギー(粒界エネルギーに相当)を与えておく，そし て, 計算格子上からランダムにある格子を選択する. 選択した 格子を結晶種 $\mathrm{i}$ 吅結晶種 $\mathrm{j}$ に変化させる $(1 \sim \mathrm{n}$ の乱数発生 $)$. そのときのエネルギー変化 $\Delta \mathrm{G}$ を計算し，(1)式の確率にした がって実行させる．つまり，粒界部にある格子は，粒界部に ない格子に比べて，異なる種類の格子に変化する確率が高く なる.この格子の変化が粒界移動(粒成長)として表現される.

固相単相組織の粒成長に関する基礎理論によれば，粒成長 の速度式は次式で表わされる.

$$
\mathrm{dr} / \mathrm{dt}=\gamma_{\mathrm{gb}} \Omega \mathrm{D}_{\mathrm{gb}} / 2 \lambda \mathrm{RT}
$$

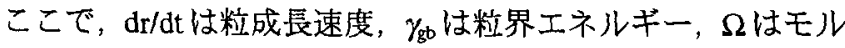
体積， $\mathrm{D}_{\mathrm{gb}}$ は粒界における原子の拡散係数，入は原子のジャン プ距離でここでは粒界の幅に相当する．つまり，MCシミュ レーションにおける粒界部での格子の変化は，基礎理論にお ける粒界を介した物質移動の意味をもつ.

Table 2 には，我々が開発を進めている焼結・粒成長のMC 法によるシミュレーションの計算用ソフトウエア(エンジン部) のプログラムおよびそれらの主な内容を示した ${ }^{13)}$.これらプ ログラムは現在も改良中であり，より多様な物質移動機構， 構成相間の反応，外力の影響などを追加予定である.

$$
3 \text { シミュレーションの研究成果 }
$$

3.1 固相焼結

Fig.2には，最も基本的な焼結シミュレーションの例とし て，2粒子間の焼結を 3 つの場合について示す ${ }^{4, の . ~(a) ~ は ~} 2$ 粒

Table 2 Outline of the original software of MC simulation for

\begin{tabular}{|c|c|}
\hline Program (Symbol) & Main Performance \\
\hline $\begin{array}{l}\text { Grain growth } \\
\text { at a solid } \\
\text { state (CG) }\end{array}$ & $\begin{array}{l}\text { Simulation for grain growth at a solid state, } \\
\text { which has variations such as pinning } \\
\text { (Zener) effect by the second particles and } \\
\text { double growth of dual phase system. }\end{array}$ \\
\hline $\begin{array}{l}\text { Grain growth } \\
\text { through liquid } \\
\text { Ostwald } \\
\text { ripening (OST) }\end{array}$ & $\begin{array}{l}\text { Simulation for the grain growth of } \\
\text { solution-reprecipitation mechanism } \\
\text { through a liquid phase. Mixed mode of } \\
\text { solid-liquid interface and solid-solid } \\
\text { interface, anisotropic growth and the } \\
\text { second solid particle can be introduced. }\end{array}$ \\
\hline $\begin{array}{l}\text { Sintering at } \\
\text { a solid state } \\
(S-S I N)\end{array}$ & $\begin{array}{l}\text { Simulation for sintering (pore shrinkage) } \\
\text { of a solid state particles accompanied by } \\
\text { grain growth. Interaction among pore, } \\
\text { grain boundary and the second particle in } \\
\text { sintering and grain growth can be } \\
\text { analyzed. }\end{array}$ \\
\hline $\begin{array}{l}\text { Liquid phase } \\
\text { sintering }(L \\
S I N)\end{array}$ & $\begin{array}{l}\text { Simulation for sintering under the presence } \\
\text { of liquid including wetting of liquid phase } \\
\text { on solid particle surface and rearrangement } \\
\text { of solid particles. Contribution of Ostwald } \\
\text { ripening, condition of liquid phase and } \\
\text { sintering of thin film on substrate can also } \\
\text { be analyzed. }\end{array}$ \\
\hline
\end{tabular}
sintering and grain growth.
子間の大きさが同じでかつ粒界が存在しない場合(例えばガラ スの焼結)，(b) は大きさは同じであるが粒界が存在する場合 (金属, セラミックス等の結晶物質), (c) は大きさも異なり粒 界も存在する場合 ( $\mathrm{b}$ と同様)である.いずれの場合も, 部算 ステップ(MCS) と共にネックの成長と 2 粒子間の接近 (収縮) による焼結が進行することが分かる．そしてこのシミュレー ションでは, (c)に示されるように焼結と共に粒成長が生じる (しかも初期段階から)ことが示されている。

Fig.3には，焼結後期においてとくに重要となるポアと粒成 長との相互作用をシミュレーションした結果を示す5,6. ポア の存在場所として, 粒内 (a), 粒界 3 重点 (b), 粒界 (c) が設定 されており，また左側の粒子(B,D)に対して右側の粒子(C,E) は粒界上にポアは存在しない形で設定されている.まず，ポ アの収縮についてみると，三重点にあったポアが最初に消滅 し，次に粒界上のポアが消滅するが，粒内のポアはほとんど 収縮しない。次に左右に配置した粒界の移動に注目すると， ポアの存在しない粒界の方が移動しやすくなっていることが 分かる.つまり，このシミュレーションではポア収縮と粒界 移動の相互作用が表現されている.
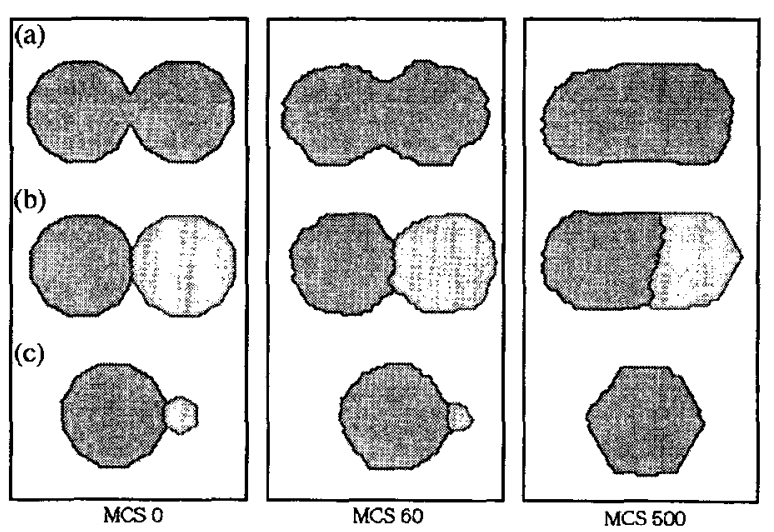

Fig.2 Simulation of solid phase sintering of two grains. (a) same size without grain boundary, (b) same size with grain boundary, (c) different size with grain boundary.

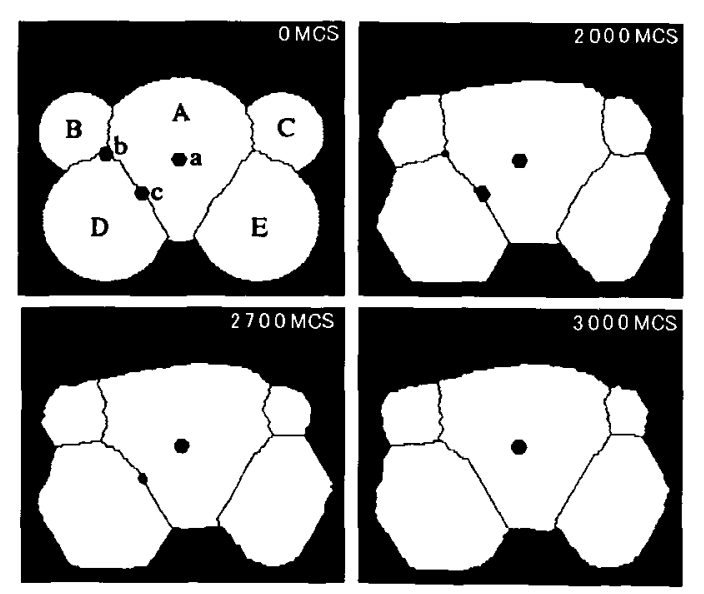

Fig.3 Simulation of interaction between pore and grain growth at a final stage of sintering. 
Fig.4には，多粒子からなる系の固相焼結および粒成長する 組織発展において, 分散粒子の効果をシミュレーションした 結果を示す7.11). (a) は固相 1 のみの場合, (b) は固相2(分散粒 子)を含むが，それは成長しない場合，(c)は分散粒子が成長 する場合である.このシミュレーションにおいては，ポアの 消滅は固相 1 では生じるが, 分散粒子では生じないと設定し ている，つまり，焼結しやすいマトリックスに比ベて，焼結 しにくい分散粒子を添加した場合の焼結現象を意味する．固 相 1 の焼結 (気孔率の減少) および粒成長は, 分散粒子のよっ て阻害されるが, 分散粒子が成長する場合の方が阻害効果が 緩和されるという結果が得られている．これは分散粒子が成 長することによって，分散粒子と隣り合うポア格子が減少し (相対的にマトリックス相と隣り合うポア格子が増加), その 結果として焼結阻害効果が減少したとして理解できる.

\section{2 液相焼結}

Fig.5には, 液相が存在する焼結過程のシミュレーションを, 2 つの固相粒子と液相 (中央の粒子) の場合について示す ${ }^{4,9}$.

(a)

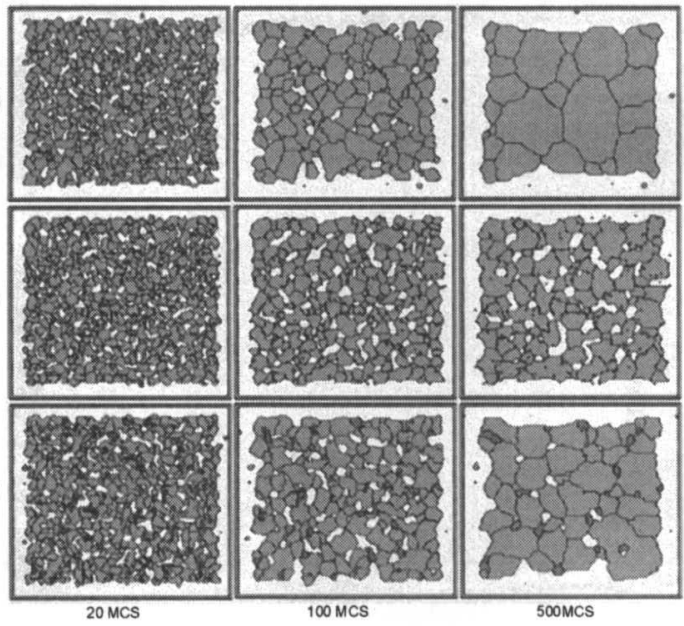

Fig.4 MC simulations of sintering and grain growth at a solid state. (a) solid 1, (b) solid 1+ solid 2 (c) solid 1+ solid 2 (growing).
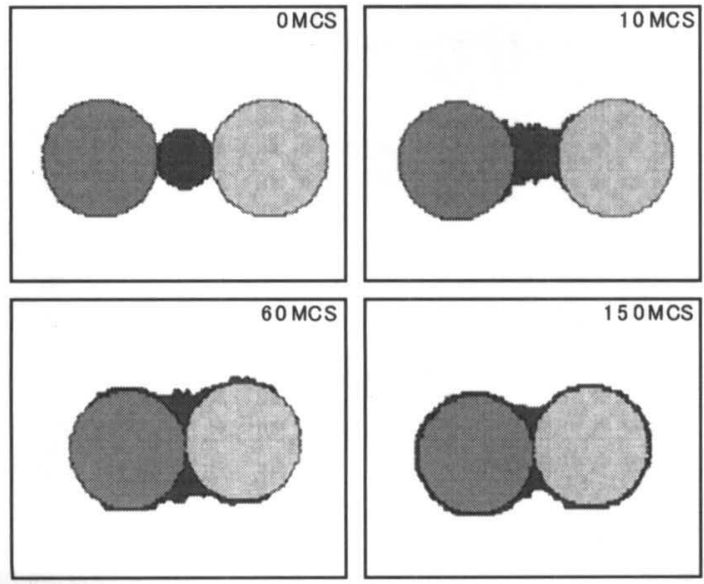

Fig.5 Simulation of sintering process under the presence of a liquid phase.
液相焼結はエネルギー関係や物質移動機構が固相焼結にくら ベて複雑である，このシミュレーションでは，液相が固相に 濡れていく過程と, 固相粒子が再配列する過程を同時に表現 している.

Fig.6には，液相の量を 5, 10, 20\%に変化させた場合のシ ミュレーション結果を, 計算ステップ(MCS)を関数にして示 す7,11). 他の計算条件は以下に示す通りである. まず初期組織 は固相, 液相 (最初は粒子状に配置)のいずれも平均粒径 (直 径) は4セルとし, ポア量 (気孔率, 外周の空間は含めない) は 30\% と一定としている. エネルギー因子としては, 固相粒 界エネルギー $\left(\gamma_{s s}\right)=1$, 固相表面エネルギー $\left(\gamma_{S v}\right)=2$, 固相 /液 相界面エネルギー $\left(\gamma_{\mathrm{SL}}\right)=0.3$, 液相表面エネルギー $\left(\chi_{\mathrm{VV}}\right)=1.5$ と 一定にしている. 物質移動因子として, 液相焼結によるポア 消滅, ポア移動の頻度因子, オストワルド (Ostwald) 成長 (拡 散律則型), マトリックス成長の頻度因子はそれぞれ, 0.1, 0.9, $0.2,0.01$ と一定に保ち, また固相に隣接したポア格子は消隇も 移動もおこらないように設定している.

シミュレーション結果をみると，いずれの場合にも計算ス テップ(MCS)の増加とともに焼結が進行し, かつ固相が成長 することが示される. 液相量が多くなるにつれて, 同じMCS で比較すると, ポアが残留しにくくなること, すなわち焼結 が促進されることが分かる.さらには, 固相粒子の成長は, 液 相量が $20 \%$ までは液相量が多くなるほど活発となるが, これ は, 液相による焼結促進でOstwald成長が起こりやすくなるた めである.

\section{3 異方粒成長}

Fig.7は液相が存在する系の固相粒子の成長について, 界面 エネルギーが等方性か異方性かの二つの場合の組織発展を示 す $^{10,11)}$. 異方性を付与すると粒子の形状が等方的 $\rightarrow$ 棒状と変化 しているのは当然であるが, 成長が等方的である場合は粒径 が揃っているのに対し, 異方性を導入した場合は粒径分布は 広がった組織を示すことが分かる.

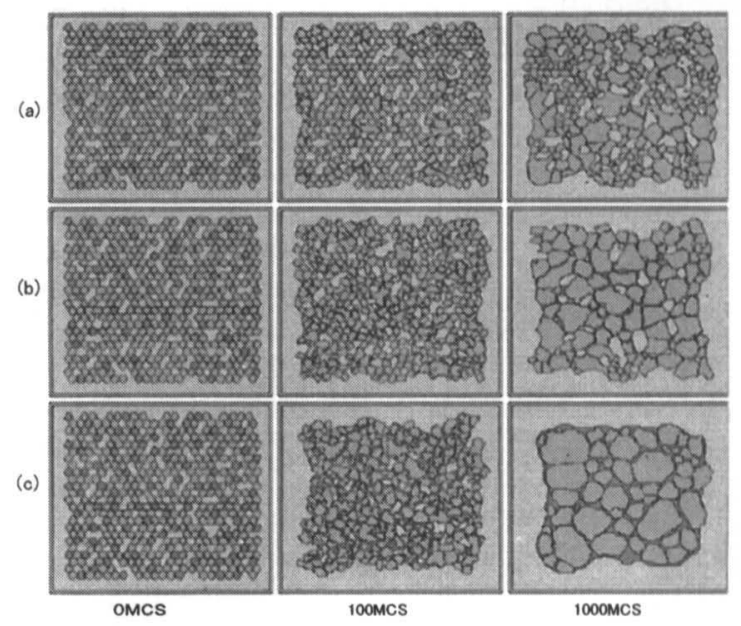

Fig.6 MC simulations of liquid phase sintering and Ostwald ripening as a function of liquid content. (a) $5 \%$, (b) $10 \%$, (c) $20 \%$. 


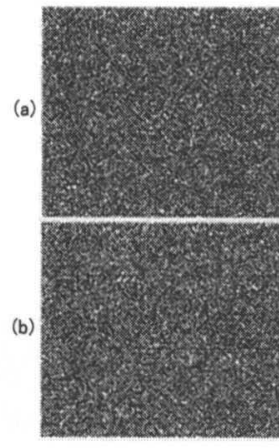

oMCS

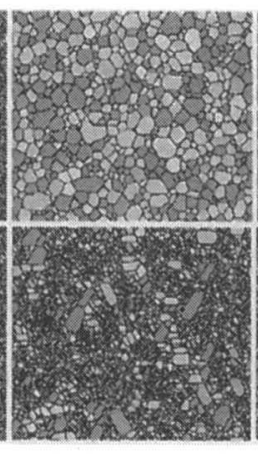

$500 \mathrm{MCS}$

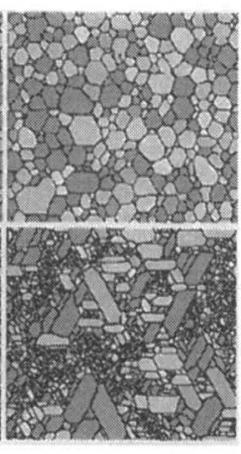

2000MCs
Fig.7 MC simulations of (a) isotropic and (b) anisotropic grain growth. Liquid content is $10 \%$.

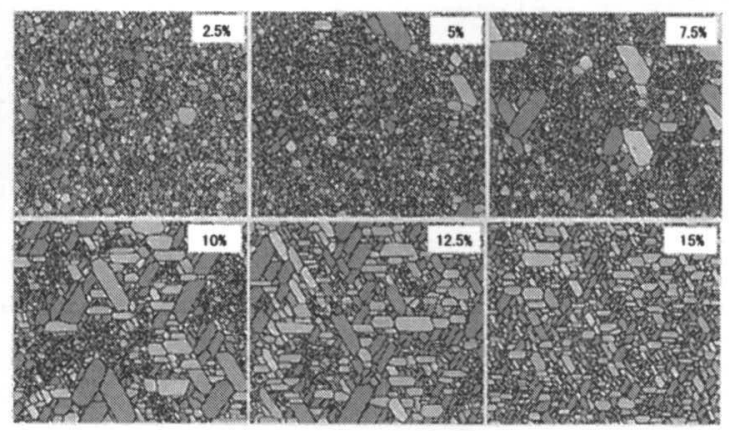

Fig.8 MC simulations of anisotropic grain growth under the presence of a liquid phase as a function of liquid content. 2000MCS.

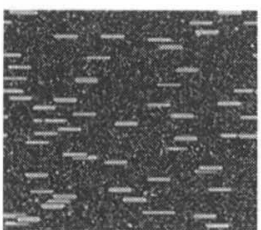

oMCS

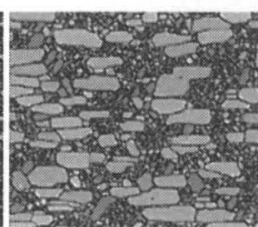

$500 \mathrm{MC}$

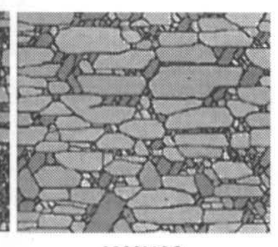

2000MCS
Fig.9 Computer simulations of microstructure development by seeding and controlling the direction in grain growth.

Fig.8には, 液相の量を細かく変えながら組織の発達の違い を調べた結果を示す ${ }^{10,11)}$. 液相量が少ない $(2.5 〜 5 \%)$, あるい は過剩な場合 (およそ $15 \%$ 以上)には, 比較的均一な組織とな るが，その中間 $(7.5 \sim 12.5 \%)$ で粒径の分極化が起こることが 分かる. このことは, 界面エネルギーに異方性がある場合に は, ある液相量の領域で, 不均一な粒成長(一種の異常粒成長 )が生じることが示される.

\section{4 シミュレーションの適用}

Fig.9には異方粒成長シミュレーションを新規材料の組織予 測に適用した一例を示す ${ }^{11)}$. 配向制御材料を例としているが, 初期組織に添加した少量の棒状の粒子により最終的に組織全

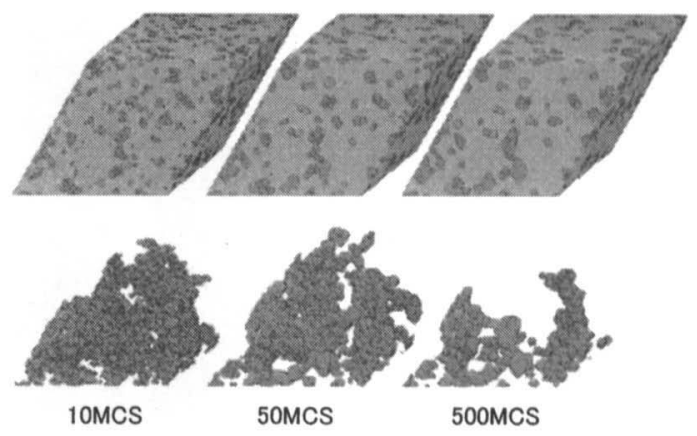

Fig.10 Three-dimensional MC simulation of the grain growth under the presence of a liquid phase (upper pictures). The bottom ones show continuous (network) structure of solid particles.
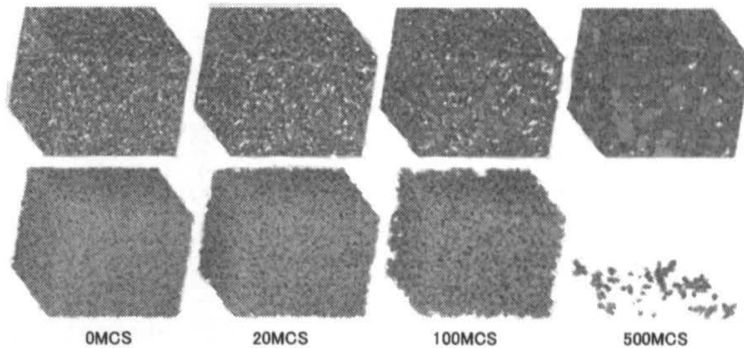

Fig.11 Three-dimensional MC simulation of sintering (upper). The bottom ones show continuous pore structure, disappearing with sintering time.

体を制御できていることが分かる. 新しい構造を有する材料 のプロセスの予備検討などで本シミュレーションの有用性は 特に大きいと考えている.

Fig.10は, 三次元の母相を介した粒成長シミュレーション を使って, 分散粒子の連続構造を設計した例である ${ }^{15)}$. 上図 は通常の構造(粒子と母相)であるが, 下図は上図から粒子だ けを抽出し, かつ連続している固相の鳥瞰図を示したもので ある. 粒子が電気伝導等の連続経路 (パーコレーション構造) をどのように形成するかなどについて設計・解析することが できる.

Fig.11は, 三次元の固相焼結のシミュレーションを行い, 通 常の組織(上図)においては固相粒子の粒径や気孔(白い部分) の分布などが分かる ${ }^{10}$. 下図は, 連続気孔のみを抽出し画像 化したものであり, 焼結が進むに連れて, 連続気孔は消滅し ていくことが分かる. フィルター等の多孔質材料の設計・解 析に応用することができる.

Fig.12には, 焼結の MC 法 (ミクロ) と有限要素法 (マクロ) を連携(連成)させたシミュレーションの例を示す. 焼結にお ける微視的および巨視的挙動をシミュレーションするために, 焼結収縮において微視的な MC 法と, 巨視的な粘塑性有限要 素法を連成させたマイクローマクロシミュレーション法を開 発している ${ }^{17)}$. MC法と有限要素法で得られた計算結果をそれ ぞれの変形ステップで交換して, 連成の効果を検討している. 


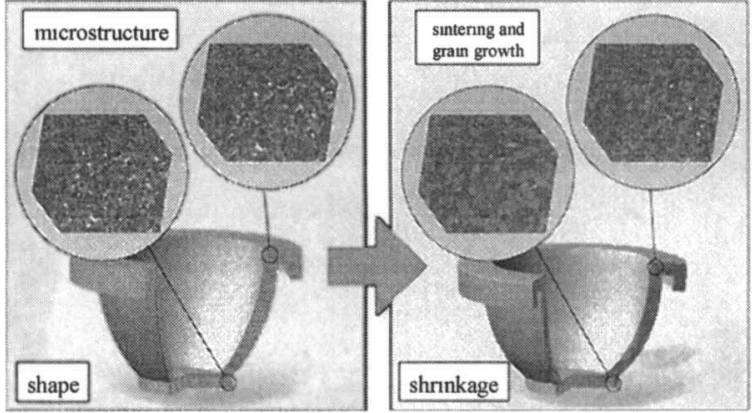

Fig.12 Computer simulation of sintering by the combined method between MC and FEM.

より具体的な焼結部品の形状予測や，異なった収縮挙動をも つ成形体の一体焼結 (共焼結) の設計等に適用が可能である. 電子セラミックス部品, センサー, 燃料電池等のより複雑な 焼結製品での利用が期待されている.

\section{5 おわりに}

焼結法の技術発展は，今後，ますます付加価値を高めた材 料・製品開発に対応した方向に向かうであろう. 異なった材 質・構造を組み合わせる(アセンブリする)焼結技術が, セラ ミックス, 金属, サーメット等の製品で多くなるに違いない. そのような焼結技術においては，もはや試行錯誤的な手法に よる問題解決が極めて困難となるだろう。 そこでは, シミュ レーション技術を使った精密な設計・解析手法が極めて有用 になるに違いない，シミュレーションによる設計技術を使い こなせるかどうかは, 創造的でかつ基礎のしっかりした材料 研究を進める上で極めて重要な要件になるのではないであろ うか. 焼結技術が，付加価値の高い材料製品の製造技術とし て，また他国に真似されにくい製造技術として発展するため に，本稿の内容が少しでもお役に立てれば幸いである．

ご興味，ご意見をお持ちの方は，JFCCのホームページ http://www.jfcc.or.jp/のCMD (Computational Material Design)研 究会を是非覗いていただきたい。電子メールでの問い合わせ は, cmd@jfcc.or.jp まで.

\section{文献}

1) H.Matsubara: "Theoretical Studies on Sintering and Grain Growth in Ceramic Materials", Bulletin Ceram. Soc. Japan, 30 (1995)385-394.

2) R.J.Brook: "Pore-Grain Boundary Interactions and Grain Growth", J. Ame. Ceram. Soc., 52(1969)56-57.

3) M.P.Anderson, D.J.Srolovitz, G.S.Grest and P.S.Sahni: "Computer Simulation of Grain Growth-I. Kinetics", Acta Metall., 32(1984)783-791.

4) H.Matsubara and R.J.Brook: "Computational Modeling of Mass Transfer for Ceramic Microstructure", Ceramic Transactions vol. 71, Am. Ceram. Soc., (1996) 403-418.
5) M.Tajika, H.Matsubara and W.Rafaniello: "Experimental and Computational Study of Grain Growth in AlN Based Ceramics", J. Ceram. Soc. Japan, 105(1997)928-33.

6) H.Matsubara: "Computer simulation Studies on Sintering and Grain Growth", Tokyo University of Science Press, SUT Bulletin, 12(1998)12-20.

7) H.Matsubara, H.Nomura, A.Honda and K.Matsunaga: "Computational Modeling of Ceramic Microstructure by MC And MD Methods", Ceramic Transactions vol. 99, Am. Ceram. Soc., (1999)97-106.

8) S.Kitaoka and H.Matsubara: "Computer Simulation of an Additive Reaction Process in Dual-Phase Microstructures", J. Ceram. Soc. Japan, 106(1998)322-26.

9) S.Kitaoka, H.Matsubara and H.Kawamoto: "Computer Simulation of Crack Propagation Path in Microstructures at Different Stages of Grain Growth", J. Ceram. Soc. Japan, 106 (1998)422-27.

10) Grain Growth in Self-Reinforced Silicon Nitride: J. Ceram. Soc. Japan, 107(1999)109-114.

11) H.Matsbara: "Synergy Ceramics", Chapter 6 "Computer Simulation for Microstructure Development", Gihodo Shuppan Co., (2000).

12) M.Tajika, H.Nomura, H.Matsubara and W.Rafaniello: "Experimental and Computational study of Grain Growth and Microstructures in AlN Composite Ceramics", J. Ceram. Soc. Japan, 108(2001)217-223.

13) H.Matsubara, C.Fisher, H.Nomura and S.Matsumoto: "Practice in Computer Simulation for Ceramic Microstructures", Bulletin Ceram. Soc. Japan, 36(2001)873-879.

14) J.Kishino, H.Nomura, S.G.Shin, H.Matsubara and T.Tanase: "Computational study on grain growth in cemented carbides", International Journal Refranctory Metals \& Hard Materials, 20 (2002)31-40.

15) M.Shimizu, H.Matsubara, H.Nomura, Y.Okuhara and H.Tomioka: "Computational Modeling of Phase Connectivity in Solid-Liquid Phase Microstructure During Grain Grain Growth", J. Ceram. Soc. Japan, 110(2002)1067-1072.

16) M.Shimizu, H.Matsubara, H.Nomura and H.Tomioka: "Computational Modeling of Phase Connectivity in Microstructures of Porous Materials during Sintering and Grain Growth", J. Ceram. Soc. Japan, 111(2003)205-211.

17) K.Mori, M.Matsubara, N.Noguchi, M.Shimizu and H.Nomura: "Micro-Macro Simulation of Sintering Process by Combining Monte Carlo and Finite Element Methods", J. Ceram. Soc. Japan, 111(2003)516-526.

18) H.Itahara, H.Nomura, T.Tani and H.Matsubara: "Design of Grain Oriented Microstructure by Using the Monte Carlo Simulation of Sintering and Grain Growth; Isotropic Grain Growth", Soc. Japan, 111(2003)548-554. 